\title{
VIMOS, VIVEMOS E VIVEREMOS
}

\author{
Josiane Javorski \\ Fernanda de Souza Fernandes \\ DOI: $h$ ttp://dx.doi.org/10.18616/intcov44
}

Ainda havia purpurina nas ruas. A chuva, em sua competência, não tinha conseguido levar o mar carnavalesco colorido e brilhante para dentro dos bueiros.

Fazia calor no trópico e o suor das nossas bocas ainda não estava censurado. Podíamos estar bem perto a ponto de falar ao pé do ouvido coisas sem méritos, porque na verdade queríamos estar na geografia entre as orelhas e o pescoço. Ali, o hálito era uma forma de presença. Podíamos suspirar sentindo os cheiros dos corpos alheios próximos, bem próximos, em emaranhados entrelaços, por vezes dentro de fervorosos abraços.

As agendas riscavam os dias ditando as expectativas de espera pela próxima viagem, pelo casamento; pela formatura; pelo nascimento; pela festa de aniversário; pelas bodas de prata; pela hora de ouro...

Mas, então, chega o aviso prévio, embora ainda não parecesse ser uma possibilidade real, e desencadeia receios: haverá casamento? Formatura? Nascimento? Como ficarão os festejos? No pensamento a certeza da merecida hora de ouro, como se não fosse possível perder de vista a travessia no gramado de um parque qualquer neste país distraído. Não, o aviso prévio não parecia ser real para nós. O mundo é grande demais!

O carro de som que subia a avenida principal, em voz afanhada, lembrava, entre o preço das batatas, que os restaurantes estariam abertos nos sábados solares por incompetência das águas de março. Bastava esperar.

Esperar, como assim? Justo nós, que almejamos as 18 horas de cada dia; as sextas-feiras; que esperamos dezembros; adiamos o uso das melhores louças e roupas; que deixamos para depois o "sim" ou "não"; "te amo"; "desapareça"; nós que deixamos para "a próxima”; que esperamos que o/a outro/a se transforme no que desejamos. 
De alguma forma inesperada, desaprendemos o que fazemos de melhor: esperar. Esperar só é bom quando se sabe o que está esperando, quando se sabe o porvir.

E agora? parecemos nos revirar no sofá da nossa própria sala, no des-conforto do nosso lar. Como se, não fosse por isso, nossa vida estaria nos eixos. Teríamos ido à academia, terminado o livro, enriquecido, resolvido o que toda a existência até agora não foi suficiente para resolver.

Agora, só esperamos que os dias se amontoem e levem nossa vida para o futuro. Um futuro que lá na frente não conseguimos alcançar. Um futuro que é esse quase ali, que nunca é aqui; que está sempre dois passos à frente. Esperamos que o futuro venha ao nosso encontro com alguma ternura, que se foi junto dos abraços que ficaram guardados para depois.

Já fez frio e a gente nem lembra do bloquinho de carnaval que participou. Os sorrisos estão embalados e são presentes íntimos, oferecidos ao final do dia, quando o fôlego volta pelos espaços entre as costelas. Os olhos voltaram a dizer tudo que sempre disseram, mas não havia ouvidos prontos. Esses olhos seguem safos, rindo dos rostos que nunca se expressaram de fato e agora lamentam a saudade dos beijos e abraços. Há pressa em contar os dias, sem saber quantos.

Empacotamos a produtividade nas compras on-line, e assim termos um fazer para descansar, quando cansarmos do que realmente precisamos fazer: pensar.

No hiato obrigatório, o espelho chamou para um duelo sem vencedores, por detrás deste nariz amassado e bochechas marcadas por elásticos curtos, o que há em nós, o que há de nós, ainda? Depois de tirar as máscaras, experimentamos o indigesto do que virá no fim: nós, sem máscaras, diante um mundo renovado nos convidando a viver a plenitude de todos esses aprendizados. 